\title{
Disharmoni Negara dan Pasar Dalam Rezim Neoliberal
}

\section{Ade Marup Wirasenjaya}

Jurusan IImu Hubungan Internasional, Fakultas IImu Sosial dan IImu Politik, Universitas Muhammadiyah Yogyakarta

Ringroad Barat Tamantirto, Kasihan, Bantul 55183

Email: addewirasenjaya@umy.ac.id

\begin{abstract}
This article tries to explain that the neoliberal regime has created an unequal relationship between state and market, especially in developing countries. The relationship between state and markets in developed countries have a different mode than similar relationship in developing countries. In developed countries, the mode of the state and market relations is "state make market". By contrast, in developing countries, the mode is "market make-state" relation. As a result of two different modes that is, neo-liberalism gave birth to the patterns of disharmony in developing countries. It brings disharmony due to domestic political life and in the context of struggle of the state in international politicaleconomy.

Keywords: neoliberal regime, disharmony, developed countries, developing countries
\end{abstract}

\begin{abstract}
Abstrak
Tulisan ini mencoba menjelaskan bahwa rezim neoliberal telah menciptakan hubungan yang tidak seimbang antara negara dan pasar, terutama di negara berkembang. Hubungan antara negara dan pasar di negara berkembang memiliki mode yang berbeda dengan hubungan yang juga sama di negara yang sedang berkembang. Di negara berkembang, mode hubungan negara dan pasar adalah "negara membuat pasar". Sebaliknya, di negara yang sedang berkembang, hubungannya adalah pasar membuat negara. Sebagai hasil, neo-liberalisme membuat pola disharmoni di negara berkembang. Menjadi disharmoni dikarenakan kehidupan politik domestik dan dalam konteks perjuangan negara di ekonomi politik internasional. Kata kunci: rezim neoliberal, disharmoni, Negara berkembang, Negara sedang berkembang
\end{abstract}

\section{PENDAHULUAN}

Arsitektur ekonomi-politik neoliberal saat ini ditandai dengan munculnya fase konsolidasi antara kekuatan negara (state) dan korporasi. Konsolidasi ini terutama berlangsung antara negara-negara yang termasuk ke dalam negara industri utama yang memiliki hubungan langsung dengan korporasi raksasa internasional. Bagi negara-negara ini, hubungan antara negara dan korporasi berlangsung secara harmonis. Sementara bagi negara-negara yang lemah dari sisi industri, hubungan negara dan rezim ekonomi internasional berlangsung secara tidak harmonis.
Tulisan ini terutama ingin memaparkan bagaimana rezim neoliberal yang memberi ruang harmonis bagi relasi negara dan pasar di negara-negara industri utama melahirkan hubungan yang tidak harmonis di negaranegara berkembang. Lebih jauh, tulisan ini akan melihat munculnya fase pendiplinan negara-negara berkembang oleh rezim pasar internasional. Pendisiplinan itu tidak semata-mata dalam konteks ekonoi, namun juga berlangsung dalam espek politik. Agendaagenda politik domestik seperti demokratisasi merupakan risiko dari pendiplinan tersebut. 


\section{PEMBAHASAN}

\section{PERTEMUAN KEMBALI NEGARA DAN PASAR DALAM STRUKTUR PASCA-FORDISME}

Fase kolonialisme telah menumbuhkan kapitalisme di negara-negara Eropa melalui arus modal yang bergerak secara langsung melalui relasi state qua state. Pertumbuhan rejim kapitalis di negara-negara Eropa seperti Belanda, Jerman, Inggris dan Prancis, Italia berlangsung dalam hubungan masing-masing negara tersebut dengan negara jajahan mereka di Asia maupun Afrika. Di kemudian hari, negara-negara Eropa yang disebutkan tersebut menjadi kampium negara kapitalis di dunia. Kolonialisme memompakkan pertumbuhan modal di dunia kapitalis. Transformasi kapitalisme pada level global berlangsung dalam transformasi negara-kolonial pada level domestik. Artinya, ketika negara-negara kapitalis utama mulai menggeser ruang kedaulatan negara ke lanskap yang lebih luas dan melampaui teritori mereka, pada saat yang sama di negara pasca-kolonial berlangsung resurgensi peran negara untuk mengatasi hambatan modal. Peran negara diperluas di negara-negara yang kuat secara ekonomi, namun mengalami reduksi pada negara-negara yang ekonominya sangat lemah.

Konsolidasi kapitalisme dibaca secara berbeda oleh sejumlah ahli. Imanuel Wallerstein (1983:13) menyebut istilah kapitalisme yang menyejarah (historical capitalism) untuk melihat tahap konsolidasi ini. Dengan menyebut kapitalisme sebagai "...the fist and foremost a historical social system”, Wallerstein melihat pengorganisasian kapitalisme sebagai struktur ekonomi yang semakin solid, menjadi sistem dunia (world system). Sistem dunia dibayangkan Wallersetein sebagai sistem ekonomi global yang memberi kemungkinan sirkulasi aktor dan pusat pertumbuhan ekonomi. Gagasan Wallerstein tentang sistem dunia secara teoritis ingin mencoba keluar dari gagasan dependensia yang melihat relasi negara pasca-kolonial dan rejim pasar dalam logika yang statis, terutama ketika mengajukan kategori center dan pheryphery atau metropolis dan satelit. ${ }^{1}$ Bagi Wallerstein, status yang diberikan kalangan dependensia tidak menjelaskan apapun atas perkembangan dunia kapitalis, terutama pengabaiannya atas negara-negara yang pernah menjadi aktor kapitalisme yang pernah ada dalam sejarah. Dalam gagasan Wallerstein, sistem dunia adalah "a unit with a single division of labor and multiple cultural system"(dalam Chilcote,1994:96) Kapitalisme berkembang dari sistem mini, sistem kekaisaran dunia dan kemudian menjadi sistem ekonomi dunia. Inti dari perkembangan ini, menurut Wallerstein, adalah munculnya proses pembagian kerja (division of labor) yang terus menerus dan lebih canggih. Dalam perkembangan itulah Wallerstein melihat ruang bagi tampilnya negara berkembang atau pinggiran untuk terlibat dalam pembagian kerja dunia kapitalis. Negara pinggiran atau pheryperi, jika berhasil terlibat dalam pembagian kerja itu, akan mengalami kenaikkan kelas menjadi negara semipheriperi, dan bukan tidak mungkin akan menjad negara center atau pusat. Itulah yang berlangsung dalam pembangunan kapitalis di negara-negara Asia seperti Korea Selatan, Jepang, Taiwan dan China dimana integrasi dengan rejim pasar global tidak selalu harus berakhir dengan eksploitasi, dominasi dan juga dependensi negara pascakolonial atas negara maju(Suwarsono dan Yo, 1991:177-204).

Sementara itu pandangan lain dikemukakan Robert W Cox yang melihat proses strukturisasi kapitalisme menjadi sangat solid setelah melewati tahap yang disebutnya competitive capitalism yang berlangsung pada pertengahan abad ke-19 dan berkembang menjadi fase monopoly capitalism sejak akhir abad ke-19.

Perkembangan dunia kapitalis, bagi Cox (1987), banyak ditentukan oleh apa yang disebut new modes of social relations of production.

Setelah fase kolonialisme berakhir di negara-negara Asia-Afrika tahun 1950-an, pola konsolidasi modal mengalami perubahan penting. Perubahan tersebut memberi jejak signifikan bagi transformasi dunia kapitalis yang semula sangat dipimpin oleh negara (state-led capitalism) menjadi kapitalisme yang terkooordiansi dalam kelahiran rejim ekonomi dunia (organized capitalism). Perlu ditambahkan, bahwa bersamaan dengan itu pusat kapitalisme mulai bergeser dari Eropa ke Amerika. Transformasi ini bukan sematamata perubahan kiblat kapitalisme, namun juga 
membawa implikasi bagi proses regimentasi ekonomi dunia. Para pengkaji ekonomi-politik dan studi pembangunan, menyebut fase konsolidasi pertama dunia kapitalis ini dengan istilah fordisme. ${ }^{2}$

Fordisme menandai konsolidasi kapitalisme sekaligus dianggap sebagai golden age of capitalism pasca perpindahannya dari Eropa ke Amerika. Istilah ini sekaligus menjadi awal dari logika kapitalisme baru dalam upaya melakukan akumulasi modal. Pada fase pra-fordisme, negara mencipta pasar - yang direpresentasikan oleh korporasi - sebagaimana sejarah kapitaisme Eropa. Namun, fase fordisme menyajikan lanskap yang memutar logika itu, dimana korporasi lah yang membawa negara ke luar dari wilayahnya, melakukan ekspansi, dan dalam banyak hal, menggerakkan negara untuk memerankan dirinya sebagai regulatory power untuk menjaga pertumbuhan pasar atau akumulasi modal (Bonano et al, 1994).

Fordisme menjadi perhatian para pengkaji teori pembangunan internasional dan hubungan internasional karena memiliki dampak pada penciptaan arsitektur ekonomi di negara kapitalis, yang selanjutnya memberi dampak bagi perluasan pasar sebagai arena ekonomi-politik. Setidaknya terdapat emat karakteristik fordisme yang dianggap menjadi panorama baru kapitalisme antara lain. Pertama, produksi bersifat masal yang didasarkan pada pembagian kerja yang rigid dan mengandalkan aliran produksi melalui jaringan distribusi (conveyor belt). Kedua, konsumsi tingkat tinggi yang didasarkan pada upah pekerja serta kehadiran organisasi pekerja sebagai bagian penting unit produksi. Ketiga, jaminan sosial (social security) sebagai bagian penting dari dunia korporasi. Dan keempat, scope perdagangan berada pada level yang lebih luas, perluasan arena ekonomi yang ditopang oleh kehadiran rejim perdagangan maupun regulasi oleh negara untuk memberi jaminan stabilitas moneter (Schmidt, 2008).

Fordisme dianggap merepresentasikan modernisasi Amerika, dan menjadi "blue print" bagi model pembangunan di banyak negara. Fordisme menjadi presentasi paling nyata dari gagasan Rostow tentang tahap paling puncak pembangunan ${ }^{3}$, yakni konsumsi tingkat tinggi (high-mass consumption). Inilah tahap yang antara lain ditandai sectors of consumer durables and service take the lead.

Bagi para pengkritik kapitalisme, fordisme menjadi awal bagi proses penundukkan (subjection) yang dilakukan oleh kalangan pemilik modal atas kaum pekerja. Fordisme dianggap sebagai momentum dimana "pasar mencari negara" untuk keperluan ekspansi modal. Kaum neo-marxis seperti Antonio Gramci bahkan memandang fordisme sebagai sebuah formasi ekonomi dan perdagangan monopolistik, atau apa yang kemudian disebut Gramci sebagai hegemoni. Gramci, seperti yang dikutip Salamini, memandang Amerikanisasi dalam fordisme sebagai:

".....requires a particular environment, a particular social structure (or least a determined intention to create it) and a certain type of State. This State is the liberal State, not in the sense of free-trade liberalism of of effective political liberty, but in the more fundamental sense of free initiative and economic individualism which, with its own means, on the level of 'civil society', through historical development, itself arrives at a regime of industrial concentration and monopoly (Salamini, 1981:149).

Hadirnya fordisme berlangsung bersamaan dengan mulai munculnya institusionalisasi ekonomi dunia. Seperti sudah disinggung di bagian awal bab ini, fordisme disebut-sebut sebagai penanda dari "the golden age capitalism" yang berlangsung kurang lebih selama tiga dasawarsa (1944-71). Pada saat yang bersamaan, proyek institusionalisasi pasar dan negara berlangsung dengan hadirnya sistem Bretton Wood.

Kehadiran fordisme yang membuat persebaran kekuatan korporasi di satu sisi, dan proses institusionalisasi yang menjadi awal bagi proses internasionalisasi negara pada sisi yang lain, merupakan momentum baru bagi kapitalisme untuk mengembangkan jejaringnya dalam tatanan dunia. Robert W Cox, seorang neo-Gramcian dalam studi hubungan internasional, menyebut periode ini sebagai periode hegemonik (hegemonic period). Bagi Cox, hegemoni kapitalisme yang menggunakan pintu masuk dunia indsutri fordistik, semakin lama mendapat 
dukungan dari proses institusionalisasi pasar.

Hegemoni berlangsung karena yang lahir dari proses ini adalah kepemimpinan moral dan intelektual, bukan semata-mata kepemimpinan ekonomi (Cox, 1987). Mulai periode ini jalur internasionalisasi bagi mode produksi fordisme diproyeksikan pada lembagalembaga internasional yang didirikan pada periode yang sama. Seperti ditulis Sussane Soederberg (2006: 6), periode ini menjadi: ....one way universal norms of a hegemonic state like the US are transmitted to other subordinat state it through international organizations, such as the United Nations, the IMF and the World Bank.

Intinya, fordisme merupakan kapitalisme yang dikendalikan oleh kekuatan terpusat meskipun pusatpusat pertumbuhan dan kekuatan pendukungnya disebar ke berbagai wilayah. Pola ini kemudian direplikasi oleh banyak perusahaan raksasa maupun oleh negara-negara maju ketika merelokasi industri mereka di negara-negara berkembang. Pada perkembangan mutakhir, logika fordisme bisa kita simak dalam bentuk bisnis franchaise yang akhir-akhir ini menjadi trend dunia. Secara singkat, kapitalisme fordisme memperlihatkan industri yang seolah-olah menyebarkan kekuasaan dan pertumbuhan, namun sebenarnya semua unit bekerja untuk menyalurkan akumulasi modal pada kekuatan sentral.

Fordisme kemudian menyebar ke berbagai penjuru dunia, seperti ke Asia. Perluasan arena negara dalam gelanggang pasar internasional banyak ditentukan oleh munculnya kekuatan korporasi dari suatu negara. Meluasnya peran negara, dengan kata lain, banyak ditentukan oleh munculnya kekuatan korporasi dari suatu negara. Negara seperti Korea Selatan, misalnya, akan memperluas peran dan posisinya sebagai liberal state seiring dengan perluasan peran yang dimainkan oleh korporasi raksasa yang lahir dari negeri ini seperti berbagai produk elektronika (Samsung, LG) maupun otomotif (KIA, Hyundai). Hal yang sama berlaku bagi Finlandia, sebuah negara kecil di Eropa, namun sejak tahun 90-an bisa memperluas arena negara ke dalam rejim internasional karena "didorong" oleh raksasa perusahaan seluler Nokia.

Sementara itu, negara-negara yang lemah secara ekonomi, yang gagal memunculkan kekuatan korporasi yang kompetitif dari negaranya, mengalami reduksi atas peran negara. Konstruksi tentang peran negara bahkan banyak ditentukan oleh posisi ekonominya dalam kelindan korporasi dan negara secara eksternal. Negaranegara yang berkutat dengan pilihan ideology, negara yang dilanda konflik etnik dan memiliki banyak kelompok politik di level domestik, dan negara yang memiliki sumberdaya alam melimpah namun gagal memunculkan korporasi, adalah gugusan negara yang lebih banyak mengalami liberalisasi dari luar dirinya. Iklim demokratisasi yang menjadi lini politik dari proses neoliberalisasi memunculkan gelombang partisipasi politik public baik melalui saluran kekuatan politik konvensional seperti partai politik maupun melalui saluran non-konvensional seperti munculnya gerakan-gerakan resistensi massa yang sporadis.

Dalam arus konsolidasi rejim neoliberal, relokasi industri merupakan salah satu bentuk paling nyata dari upaya integrasi negara berkembang ke arena pasar global. Di negara pasca-kolonial seperti Indonesia, relokasi industri ini menempatkan Indonesia sebagai basis produksi bagi sejumlah merek dunia seperti dalam kasus pendirian pabrik otomotif dan elektronik dari Jepang dan Korea di Indonesia, pabrik sepatu dan konveksi milik korporasi besar seperti Nike dan GAP dan lain-lain. Indonesia memberi tempat yang layak bagi ekspansi korporasi tersebut dengan menyediakan para pekerja, yang dalam standar negara pusat kapitalisme, diupah sangat murah.

Berubahnya pola-pola produksi membuat segregasi negara oleh pasar sebagaimana diajukan oleh pandangan liberalisme, berakhir. Perubahan ini juga memberi ruang konstruksi baru tentang relasi negara dan pasar. Gagasan tentang pasar mengalami perubahan penting dalam fase ini. Bagi kalangan neoliberal, pasar tidak lagi dipahami sebagai sebuah tatanan atau struktur ekonomi, tetapi merupakan struktur sosial. Pemahaman ini mengandaikan bahwa dunia sosial, termasuk sistem politik, tidak lagi hadir dalam arena terpisah dari pasar, namun juga memberi proteksi dan mengawal pasar agar bisa bekerja menurut hukum-hukumnya. 
Lebih jauh, Bonano dkk (1994) membuat konstruksi negara pada fase pasca Fordisme di Asia. Pada fase ini, negara merupakan entitas yang hidup dalam kontrol sosial. Argumen ini mengemukakan bahwa arena kedaulatan dan peran negara akan diperluas oleh kehadiran struktur ekonomi global, terutama karena kehadiran perusahaan trans-nasional. Peran negara-negara maju diperluas bersamaan dengan tumbuhnya perusahaan dan korporasi raksasa yang memiliki hubungan dengan mereka. Intrusi rejim pasar di level domestik, di sisi negara pasca-kolonial, justru semakin menciptakan kelas sosial baru yang kehadirannya menuntut peran negara untuk memberi perlindungan bagi akumulasi modal. Negara juga menjadi mitra korporasi internasional yang operasinya menuntut perluasan peran negara, sepanjang perluasan itu memberi perlindungan bagi arus akumulasi capital.

Konsolidasi pasar dan negara seperti yang dilakukan oleh rejim neoliberal tidak banyak menyebarkan pendapatan ke berbagai belahan dunia. Kenyataannya, konsentrasi modal berlangsung hanya di negara-negara yang memiliki hubungan langsung dengan berbagai perusahaan raksasa. Salah satu kecenderungan praktik neolibralisme dalam mengkonsolidasi negara dan pasar adalah mumculnya institutusi yang bisa menjembatani bekerjanya pasar dan negara.

Hadirnya institusi-institusi ini pada satu sisi memberi persuasi kepada masyarakat internasional tentang globalisasi dunia dimana semua aktor memiliki posisi, peluang dan kesempatan yang sama untuk terlibat di dalamnya. Argumen ini memang khas kalangan hiperglobalis yang melihat bahwa globalisasi dibayangkan akan memberi "berkah" bagi semua negara dan semua negara berposisi setara dalam konstelasi ekonomi-politik dunia (Held, 1999). Eksponen yang mendukung pandangan ini antara lain kalangan multi-nasional dan negara-negara industri. Namun demikian, institusi internasional yang menopang neoliberalisme sesungguhnya merupakan korporasi. Kalangan pessimist globalist seperti Hist dan Thompson (2001) menyebut bahwa globalisasi yang fair dan memberi ruang setara bagi semua negara sebenarnya tak pernah ada. Keduanya juga menyangsikan tentang kiprah trans-national corporations (TNC) dalam kontribusinya bagi keadilan ekonomi dunia. Perusahaan transnasional yang benar-benar murni tidak pernah ada. Hampir semua TNC besar dunia pada umumnya berbasis negara nasional dan kegiatan perdagangan mereka di seluruh dunia bertumpu pada kekuatan produksi dan pemasaran di lokasi nasional. Selain itu, keduanya juga menunjukkan sejumlah temuan bahwa lalu-lintas modal tidak mengakibatkan berpindahnya penanaman modal dan kesempatan kerja secara besar-besaran dari negara maju ke negara berkembang. Sebaliknya, penanaman modal asing (foreign direct investment) justru banyak terpusat di negara-negara industri maju, sementara mayoritas Dunia Ketiga tetap menempati posisi di pinggiran baik dari sisi investasi dan perdagangan (Hirst dan Thompson, 2001).

Perusahaan multi-nasional, negara-negara industri utama dan lembaga-lembaga keuangan dan perdagangan multilateral telah membentuk pakta dominasi dalam arsitektur ekonomi global. Bagi para pengkritiknya, tiga gugus globalisasi tersebut membangun koordinasi, baik yang secara laten maupun secara manifest, untuk mengatur pasar dan aspek-aspek ekonomi lainnya. Pasar yang murni, yang menjalankan modus invisible hands - sebagaimana keyakinan kaum Smithian, sebenarnya tak pernah berlangsung. Pasar, seperti ditegaskan kembali oleh Hirst dan Thompson (2001), bukanlah entitas yang tidak bisa dikendalikan dan sama sekali tidak punya imunitas dari kepentingan pakta dominasi. Pasar selaku punya jejak dan afinitas struktural dengan lembaga-lembaga dominan yag hadir pada fase neoliberal saat ini.

\section{NEOLIBERALISME DAN MITOS INVISIBLE HANDS}

Argumen tentang bekerjanya pasar secara swatata (self-regulating) dalam kapitalisme membuat diyakini oleh Karl Polanyi dalam Great Transformation. Bayangan tentang kapitalisme yang "akan bekerja secara alamiah" sebagaimana keyakinan kaum liberal nampaknya kian tidak bisa dilacak pada fase neoliberalisme atau 
globalisasi. Sementara bayangan kaum marxis yang melihat ada kontradiksi internal yang akan menghentikan laju kapitalisme, juga tidak kunjung terwujud. Soliditas kapitalisme dalam struktur keuangan dan perdagangan internasional memunculkan konstruksi yang mencerminkan bahwa pasar terlalu politis untuk dilihat sebagai gejala ekonomi dan terlalu ekonomik untuk dilihat secara politis. Baik kekuatan ekonomi yang tercermin dari pertumbuhan korporasi internasional maupujn entitas politik seperti negara pada gilirannya menjadi dua entitas paling penting dalam mengkonstruksi rejim pasar global.

Karl Polanyi menyebut kapitalisme sebagai sebuah transformasi besar dalam ekonomi dunia. Transformasi itu berlangsung ketika negara hadir sebagai institusi yang menjembatani kepentingan pasar dan masyarakat industri. Meski demikian, Bagi Polanyi, kapitalisme memiliki ciri utama yakni sifatnya yang swatata (selfregulate). Ekonomi pasar atau kapitalisme, adalah ekonomi yang dikendalikan, diatur dan diarahkan oleh pasar sendiri dimana tatanan produksi dan distribusi barang-barang dipercayakan kepada mekanisme swatata tersebut (Polanyi, 2003:92).

Gagasan dan kontruksi tentang kapitalisme Polanyi sebenarnya merupakan tafsir ulang atas gagasan pasar yang dipahami kaum liberalism klasik seperti Adam Smith. Bagi Polanyi, tak ada satupun entitas di luar pasar yang bisa campur tangan untuk mengendalikan proses berlangsungnya hukum pasar, termasuk di dalamnya negara. Swatata atau self-regulating market dipahami sebagai, semua produksi akan dijual di pasar dan semua pendapatan berasal dari penjualanpenjualan semacam itu Polanyi pada akhirnya menegaskan bahwa intitusionalisasi pasar hanya tumbuh dalam masyarakat pasar (Polanyi, 2003:93). Meskipun demikian, Polanyi melihat bahwa kaum liberal dan juga pengkritiknya dari kaum marxis samasama memberi postulasi yang menghambat bekerjanya pasar swatata. Dalam pandangan Polanyi, baik kaum liberal maupun marxis: "tidak lebih hanya menghalangi sebuah pandangan menyeluruh tentang masyarakat pasar." Dengan cara pandang seperti itu, kaum liberal dan kaum marxis sebenarnya berada pada level analisis yang sama ketika kedua pandangan tersebut menempatkan kelas sosial sebagai pembentuk pasar. Kepentingan kelas, bagi Polanyi, hanya menawarkan penjelasan yang terbatas tentang gerakangerakan yang panjang di masyarakat. Polanyi bahkan menggunakan logika Marxian untuk mengkritik pandangan kaum marxis: nasib kelas sebenarnya lebih sering ditentukan oleh kebutuhan-kebutuhan masyarakat ketimbang nasib masyarakat ditentukan oleh kebutuhan kelas (Polanyi, 2003:206).

Gagasan tentang pasar swatata sebenarnya lebih banyak didasarkan pada harapan Polanyi tentang pasar yang seharusnya bekerja dan mengkonsolidasikan dirinya dilihat dari evolusi pasar sejak Revolusi Industri. Berbagai momentum sejarah dimana perdagangan dunia mencapai pada bentuknya yang mampu mengakomodasi semua aktor perdagangan seperti pada abad ke 18 dan 19, dibayangkan Polanyi sebagai gugusan sejarah yang kelak akan membentuk pasar swatata. Namun, kekuatan ekonomi dunia yang semula bersumber dari negara-negara pasca-kolonial, justru mengalami strukturisasi yang amat rigid dan timpang pada abad ke 20 hingga sekarang. Dengan kata lain, pasar swatata yang dibayangkan Polanyi mengalami keruntuhan ketika pelaku-pelaku ekonomi dunia dari bekas negara penjajah menjadi kekuatan ekonomi raksasa dan serangkaian kebijakan penyesuaian terhadap struktur kapitalisme tersebut semakin menciptakan hadirnya aspek non- ekonomi dalam integrasi negara pasca-kolonial terhadap rejim pasar global.

Kegagalan imajinasi Polanyi tentang pasar yang "bekerja untuk dirinya sendiri", serta absennya kekuatan revolusi sebagaimana dibayangkan kalangan marxis, membuat agenda rejim neoliberal semakin kuat. Ekspansi pasar dalam rejim neoliberal ditandai dengan posisi yang berubah dari status negara dan pasar di negara-negara yang ekonominya sangat kuat di negara-negara maju seperti Amerika dan Eropa Barat disbanding dengan relasi pasar dan negara yang berlangsung di negara pasca-kolonial. Di negara-negara yang ekonominya sangat kuat, terjadi gejala negara 
mencipta pasar (state make market), sedang di negara pasca colonial, berlaku sebaliknya dimana pasar mencipta negara (market make state).

Momentum state make market bisa ditelusuri pada rentang fase kolonialisme ketika bangsa-bangsa Eropa mengirimkan utusan dagangnya untuk mengambil barang-barang mentah dan hasil bumi dari tanah jajahan mereka di Asia, Afrika dan juga Amerika Latin. Setelah negara-negara berkembang tersebut menjadi negara merdeka secara formal, momentum state make market tersebut berlanjut dalam pembentukkan lembaga-lembaga pemberi bantuan, supervisi maupun asistensi proyek-proyek pembangunan negara-negara pasca-kolonial. Negara-negara bekas penjajah terlibat dalam evolusi rejim ekonomi internasional seperti IMF, Bank Dunia dan WTO yang kemudian menjadi pilar penting bagi hubungan baru negara-negara maju dan berkembang. Prinsip pengambilan suara yang didasarkan pada besarnya jumlah donasi pada lembagalembaga tersebut semakin memperkuat bahwa pasar swatata sebenarnya tak pernah ada.

Sebaliknya, gejala kedua - dimana pasar mencipta negara - bisa ditelusuri dalam serangkaian operasi maupun regulasi yang dihasilkan rejim ekonomi global yang kemudian menjadi blue-print politik di banyak negara pasca-kolonial. Seperti yang ingin dibuktikan tesis ini, fenomena market make state begitu kuat dalam agenda-agenda politik dari rejim pasar bebas di negara pasca-kolonial seperti Indonesia.

\section{PENDISIPLINAN NEGARA OLEH PASAR}

Susan Strange, seorang neo-strukturalis dalam studi hubungan internasional mengajukan konsep structural power saat mengkaji hubungan negara dan pasar pada era globalisasi. Dalam karyanya yang berpengaruh, State and Market, Strange (1988) melihat pola kekuasaan pada masa rejim neoliberal adalah kekuasaan yang tidak langsung, yakni kekuasaan yang didasarkan pada pembagian kerja antar institusi-institusi internasional yang ada, khususnya institusi ekonomi internasional. Susan Strange memberikan pengertian tentang kekuasaan struktural yang berbeda dengan pandangan kaum realis dalam studi hubungan internasional yang memandang kekuasaan dalam konteks relasional. Perbedaan penting dari gagasan kekuasaan tersebut terletak pada implikasi dari pola-pola hubungan yang tercipta antara aktor yang ada. Dalam pandangan realis, kekuasaan dipahami dalam evidensi material yang didapat. Sementara kekuasaan struktural lebih menakankan bentuk pendisiplinan yang berjangka panjang, sebuah upaya sistematis untuk menciptakan ketergantungan-esok (future dependency) bagi aktor-aktor sub-ordinat dalam struktur yang ada. Karena sifatnya yang struktural dan skope-nya yang mendunia, integrasi dengan struktur-struktur ekonomi dan politik dunia adalah jalan rasional, namun ada banyak pertaruhan bagi negara-negara pinggiran yang ekonominya sangat lemah untuk mendapatkan berbagai keuntungan.

Pada masa Pemerintahan George Bush, dunia gagasan Amerika Serikat dalam memandang dunia dipengaruhi oleh jaringan neo-konservatif ${ }^{4}$ yang kurang lebih memiliki empat pandangan (doktrin) utama. Pertama, mereka memandang dunia secara hitam-putih dengan kategori moral yang amat absolut. Kedua, mereka fokus pada Amerika sebagai kekuatan unipolar dunia, yang juga memberi rekomendasi bagi penggunaan kekuatan militer untuk melindungi kepentingan global Amerika. Ketiga, juga mengemukakan slogan (watchword) "global unilateralism" yang memberi rekomendasi Amerika untuk berkpirah dan menentukan dalam lembaga multilateral. Dan keempat, mereka melihat fase Reagen sebagai sebuah warisan (legacy) penting yang harus dilanjutkan oleh Amerika (saat ini) untuk mengambil peran lebih besar dalam institusi global (Halper dan Clarke, 2004: 11).

Seperti dicatat dalam sejarah, era Ronald Reagan (1981-1989) disebiut-sebut sebagai era penguatan paham neoliberalisme global. Bersama kompatriotnya Margareth Teacher di Inggris waktu itu, keduanya mengembangkan mazhab Reaganomics dan Thatchernomic, yang membawa dunia pada fase neoliberal selama satu dasawarsa. Kedua mazhab tersebut percaya pada kompetisi sebebas-bebasnya dalam bidang ekonomi, namun pada saat yang sama negara hadir sebagai kekuatan yang sangat kuat untuk 
mengontrol ekonomi. Dengan kebijakannya itu, Presiden Reagan berfokus pada penyegaran stagnasi kondisi ekonomi, inflasi dan pengangguran.

Pemotongan pajak juga bergabung dengan pengeluaran militer yang besar sebagai akibat yang amat tinggi dan pertambahan dramatis dalam utang nasional. Utang bertambah dengan sekitar 200\% (3 kali lipat) antara saat Reagan menjabat dan saat penggantinya George $\mathrm{H}$. W. Bush, menduduki jabatan. Kebijakan ekonomi Reagan tersebut membawa ketimpangan pada masyarakat Amerika dimana 10 persen teratas penduduk Amerika meningkat pendapatannya 16 persen, 5 persen teratas meningkat pendapatannya 23 persen, dan 1 persen teratas meningkat pendapatannya sejumlah 50\%. Ini kontras jika dilihat dari sisi sebaliknya, dimana 80 persen terbawah kehilangan pendapatan dan yang terbawah (10\% terbawah) kehilangan pendapatan 15\% (Setiawan, 2009).

Pendisiplinan negara oleh pasar segera terlihat ketika negara-negara berkembang seperti Indonesia menyetujui Letter of Intent (LoI) bersama IMF. Bahkan, pengaruh struktur ekonomi neoliberal semakin besar ketika lembaga keuangan tersebut turut menentukan penyusunan Repelita dan Garis-garis Besar Haluan Negara (GBHN) di tahun 1998 (Setiawan, 2009:20). Padahal, Repelita dan GBHN merupakan blue print kebijakan pembangunan domestik yang mencerminkan kedaulatan negara dan menjadi representasi dari bekerjanya pemerintahan.

\section{KESIMPULAN}

Uraian di atas sangat jelas menunjukkan bahwa pengaruh ketergantungan terhadap lembaga ekonomi internasional tidak melulu berdampak pada dimensi ekonomi, tetapi juga pada aspek yang lebih fundamental seperti kedaulatan, bahkan konstitusi. Maka, ketika intrusi IMF berlangsung pada penyusunan Repelita dan GBHN, hal ini akan membawa implikasi yang hebat pada posisi negara, kapasitas pemerintahan, juga pada makna keterlibatan kekuatan politik domestik. Dengan pembacaan in pula, momentum campur tangan IMF dalam penyusunan Repelita dan GHBN, sebenarnya merupakan reduksi atas peran-peran aktor politik, sebuah "kudeta struktural" yang amat nyata yang akan mempengaruhi relasi negara dan masyarakat di Indonesia saat ini.

\section{CATATAN AKHIR}

1 Dalam gagasan Paul Baran, seorang eksponen dari pandangan dependensia, perkembangan kapitalisme di negara-negara pusat sangat berbeda dengan perkembangan kapitalisme di negaranegara pinggiran. Di negara pusat, kapitalisme bisa berkembang antara lain karena surplus yang ada di tangan pedagang dan tuan tanah diinvestasikan ke bidang industry. Sementara di negara kapitalis pinggiran yang terjadi justru sebaliknya dimana munculnya kekuatan ekonomi asing dalam bentuk penetrasi modal dari negara maju membuat surplus yang terjadi di kawasan pinggiran diambil kembali oleh kekuatan eksternal atau kaum pendatang. Lihat misalnya Paul Baran, The Political Economy of Growth, Penguin Books, Australia, 1957. Juga review atas pemikiran Baran oleh Arief Budiman, Teori Pembangunan Dunia Ketiga, Gramedia Jakarta, hal, 57-58.

2 Fordisme adalah istilah yang dikemukakan oleh sebuah mazhab dalam teori pembangunan internasional, yakni mazhab regulation theory. Fordisme merujuk pada jaman emas kapitalisme tahun 1945-1973 atau sering disebut fase finance-led growth regime dimana Amerika menjadi tipikal kesuksesan dunia kapitalis. Fordisme mengacu pada pola-pola produksi baru kapitalisme yang mengikuti cara perusahaan otomotif Ford dari Amerika dalam mengakumulasi modal. Secara singkat, fordisme mengacu pada sistem produksi missal dan konsumsi tingkat tinggi, ekspansi bisnis namun tetap dikontrol oleh si pemilik modal. Untuk elaborasi fordisme, lihat misalnya Bonano et.al, "Global Post-Fordisme and Concept of The State", dimuat dalam International Journal of Sociology of Agriculture and Food, volume 4 tahun 1994. Juga artikel Gert Schmidt, "Globalization and Asian Fordism", dalam jurnal Globality Studies, No.11, tahun 2008.

3 Gagasan Rostow tentang lima tahap pembangunan yang ditulis dalam bukunya, The Stage of Economic Growth (1968) telah dianggap "kredo" dan prototype modernisasi di banyak negara. Menurut Rostow, lima tahap pembangunan tersebut adalah tahap masyarakat tradisional, tahap pra kondisi tinggal landas, tahap tinggal landas, tahap kematangan dan tahap konsumsi massa tingkat tinggi. Lihat Richard Peet dan Elanie Hartwick, Theories of Development, The Guilford Press, New York, 1999.

$4 \quad$ Neo-konservatisme adalah paham yang memadukan gagasan moral, politik dan ekonomi sekaligus. la adalah bentuk ortdhodoksi atas gagasan kapitalisme dan liberalisme. Buku menarik yang mengupas pengaruh neo-konservatif dalam pemerintahan Amerika di bawah Bush misalnya adalah America Alone: The NeoConservatives and The Global Order karya Stefan Halper dan Jonathan Clarke, Cambrige University Press, 2004. Dalam buku itu, keduanya melihat neokonservatif sebagai sebuah jaringan dan gerakan tanpa kartu nama, tanpa sekretariat, namun cukup memiliki pengaruh dalam administrasi pemerintahan Bush. Dalam bahasa keduanya, neo-konservatisme merupakan: " . ....not a-cardcarrying organization. They do not hold meeting or convention. 
There in no absolute dividing line between who is and who is not a neo-concervatives...", ibid, hal.10.

\section{REFERENSI}

Alvin S Yo dan Soewarsono. 1991. Perubahan Sosial dan Pembangunan di Indonesia. Jakarta: LP3ES.

Paul Baran, Paul.1957. The Political Economy of Growth, Australia: Penguin Books.

Budiman, Arief. 1992.Teori Pembangunan Dunia Ketiga, Jakarta: Gramedia.

Bonano et.al, "Global Post-Fordisme and Concept of The State", dimuat dalam International Journal of Sociology of Agriculture and Food, volume 4 tahun 1994. Juga artikel Gert Schmidt, "Globalization and Asian Fordism", dalam jurnal Globality Studies, No.11, tahun 2008

Cox, Robert W. 1987. Production, Power and World Order: Social Forces in the Making of History. Columbia University Press.

Chilcote, Roland.1994. Theories of Development and Under-development, Colorado: Westview Press.

Halper, Stefan dan Jonathan Clark. 2004. America Alone: The NeoConservatives and The Global Order. Cambrige University Press.

Hisrt, Paul dan Grahame Thompson. 2001. Globalisasi adalah Mitos (terj). Jakarta: Yayasan Obor Indonesia.

Polanyi., Karl. 2003.Transformasi Besar: Asal-usul, Politik dan Ekonomi Zaman Sekarang (terj.) Yogyakarta: Pustaka Pelajar.

Strange, Susan.1988. State and Market. London: Pinter Publisher.

Salamini, Leonardo. 1981. The Sociology of Political Praxis: An Introduction to Gramci's Theory. London: Routledge and Kegan Paul.

Setiawan, Bonny "Neoliberalisme sebagai Kejahatan Rezim Global”, dalam Jurnal Global Justice Update, diterbitkan oleh Institute for Global Justice, Jakarta, edisi khusus, 2009

Soederberg, Susanne. 2006. Global Governance in Question: Empire, Class and New Common Sense in Managing North-South Relations, London: Pluto Press.

Wallerstein, Immanuel. 1983. Historical Capitalism, London: Verso. 